\title{
Rhizobacteria Isolated from Saline Soil Induce Systemic Tolerance in Wheat (Triticum aestivum L.) against Salinity Stress
}

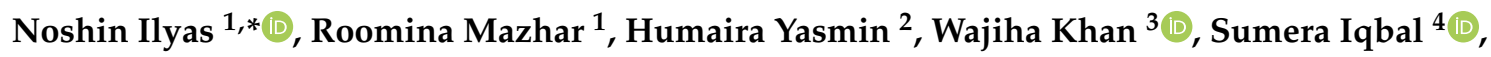 \\ Hesham El Enshasy ${ }^{5,6,7, *}$ and Daniel Joe Dailin ${ }^{5,6}$ \\ 1 Department of Botany, PMAS-Arid Agriculture University, Rawalpindi 46300, Pakistan; \\ roominamazhar83@gmail.com \\ 2 Department of Bio-Sciences, COMSATS University, Islamabad 45550, Pakistan; \\ humaira.yasmin@comsat.edu.pk \\ 3 Department of Biotechnology, COMSATS University Islamabad, Abbottabad Campus, \\ Abbottabad 22010, Pakistan; wajihak@cuiatd.edu.pk \\ 4 Department of Botany, Lahore College for Women University, Lahore 54000, Pakistan; \\ sumeraiqbal2@yahoo.com \\ 5 Institute of Bioproduct Development (IBD), Universiti Teknologi Malaysia (UTM), \\ Skudai, Johor 81310, Malaysia; jddaniel@utm.my \\ 6 School of Chemical and Energy Engineering, Faculty of Engineering, Universiti Teknologi Malaysia (UTM), \\ Skudai, Johor 81310, Malaysia \\ 7 City of Scientific Research and Technology Applications (SRTA), New Burg Al Arab, Alexandria 21934, Egypt \\ * Correspondence: noshinilyas@yahoo.com (N.I.); henshasy@ibd.utm.my (H.E.E.)
}

Received: 8 June 2020; Accepted: 23 June 2020; Published: 10 July 2020 updates

\begin{abstract}
Halo-tolerant plant growth-promoting rhizobacteria (PGPR) have the inherent potential to cope up with salinity. Thus, they can be used as an effective strategy in enhancing the productivity of saline agro-systems. In this study, a total of 50 isolates were screened from the rhizospheric soil of plants growing in the salt range of Pakistan. Out of these, four isolates were selected based on their salinity tolerance and plant growth promotion characters. These isolates $\left(\mathrm{SR}_{1} . \mathrm{SR}_{2}, \mathrm{SR}_{3}\right.$, and $\left.\mathrm{SR}_{4}\right)$ were identified as Bacillus sp. (KF719179), Azospirillum brasilense (KJ194586), Azospirillum lipoferum (KJ434039), and Pseudomonas stutzeri (KJ685889) by 16S rDNA gene sequence analysis. In vitro, these strains, in alone and in a consortium, showed better production of compatible solute and phytohormones, including indole acetic acid (IAA), gibberellic acid (GA), cytokinin (CK), and abscisic acid (ABA), in culture conditions under salt stress. When tested for inoculation, the consortium of all four strains showed the best results in terms of improved plant biomass and relative water content. Consortium-inoculated wheat plants showed tolerance by reduced electrolyte leakage and increased production of chlorophyll a, b, and total chlorophyll, and osmolytes, including soluble sugar, proline, amino acids, and antioxidant enzymes (superoxide dismutase, catalase, peroxidase), upon exposure to salinity stress $(150 \mathrm{mM} \mathrm{NaCl})$. In conclusion, plant growth-promoting bacteria, isolated from salt-affected regions, have strong potential to mitigate the deleterious effects of salt stress in wheat crop, when inoculated. Therefore, this consortium can be used as potent inoculants for wheat crop under prevailing stress conditions.
\end{abstract}

Keywords: salinity; PGPR; wheat; compatible solutes; antioxidant enzymes

\section{Introduction}

Globally, the production rate of agriculture is far less than the estimated food requirement of the ever-increasing population and the gap will be widened over time [1] (GAP Report, 2018). 
Agro-ecosystems are influenced by environmental and climatic conditions, farming techniques, and management practices. It is estimated that internationally, salinity affects $22 \%$ of the total cultivated and $33 \%$ of the total irrigated agricultural area, which is increasing at an alarming rate of $10 \%$ annually. Pakistan is also facing severe salinity issues and a total area of 6.30 million hectares is salt affected, out of which 1.89 million hectares is marked as saline [2].

Due to a higher concentration of sodium chloride $(\mathrm{NaCl})$, plants growing in salt-affected soils suffer from both hyperosmotic and hyperionic effects. These stresses result in reduced water uptake; altered ion and mineral absorption rates; increased production of reactive oxygen species, causing disorganization of the cell membrane; and reduction of metabolic activities [3]. Halophytes adapt themselves to saline conditions by adjusting their physiological activities, maintaining their water balance by osmotic adjustments, producing compatible solutes, and modifying the antioxidant system [4]. Some plants overcome salinity stress through the production of osmolytes, particularly glycine betaine, proline, soluble sugars, and proteins [5].

Improvement in the crop yield of saline soils requires a multidimensional approach consisting of salt-tolerant varieties or amelioration by chemical neutralizers, but there is a dire need for eco-friendly sustainable approaches. Rhizobacteria, showing potential to improve plant growth, are termed as plant growth-promoting rhizobacteria (PGPR) [6]. PGPR have the potential to improve plant growth through various mechanisms, including better plant growth, the production of phytohormones, and amelioration of stresses [7]. Due to the natural coping mechanisms of PGPR, their inoculation can help the amelioration of various abiotic stresses in plants. PGPR inoculation can help to improve the growth and yield of crops, particularly in regions prone to drought and salt stress [8,9]. Natural halotolerant PGPR strains have better potential for the amelioration of salt stress in regional crops for sustainable yields. These native PGPR strains are well acclimated to indigenous conditions and the plant-microbe interactions can help the plants to tolerate stress [10].

In this study, native halotolerant PGPR strains were isolated from local saline soils, and their ability to promote plant growth when inoculated under salt stress was investigated. The objective of the present research was to focus on the evaluation of isolated bacterial strains to stimulate salinity tolerance and the promotion of wheat growth, as well as the identification and characterization of the candidate strain both bio-physiochemically and genetically. This study provides a basis to identify and characterize PGPR from natural saline conditions and testing their potential for improving salinity tolerance in wheat, the major staple crop across the world.

\section{Materials and Methods}

\subsection{Soil Sampling and Physicochemical Analysis}

The rhizospheric soil of four halophytes namely, Abutilon bidentatum, Maytenus royleanus, Leptochloa fusca (Kallar grass), and Dedonia viscose, was collected from a salt range of Pakistan (313-360 m.a.s.l; $32^{\circ} 23-33^{\circ} 00$ north latitude and $71^{\circ} 30-73^{\circ} 30$ east longitude). The rhizospheric soil was sieved and stored at $4{ }^{\circ} \mathrm{C}$ for future analysis. Rhizospheric soil was analyzed for $\mathrm{pH}$ and electrical conductivity (EC) [11], soil texture, macro and micronutrients [12], and available nutrients [13].

\subsection{Strain Isolation and HaloTolerance Assay}

Rhizobacteria were isolated from rhizospheric soil of Abutilon bidentatum, Maytenus royleanus, Leptochloa fusca, and Dedonia viscose by using the serial dilution and spread plate techniques [14]. The soil suspension was made by adding $1 \mathrm{~g}$ of soil in $9 \mathrm{~mL}$ of Milli-Q distilled water. An aliquot of soil suspension was inoculated on Luria-Bertani (LB) agar plates and incubated at $28 \pm 2{ }^{\circ} \mathrm{C}$ for $48 \mathrm{~h}$. The obtained colonies were purified by sub-culturing. The colony-forming unit (CFU) was calculated according to the formula given by [15]:

$\mathrm{CFU} / \mathrm{g}=($ colonies number $\times$ dilution factor/volume of inoculum $)$. 
Distinct bacterial colonies were examined for colony characteristics (shape, size, margin, elevation, appearance, texture, pigmentation, and optical properties) as well as for cellular characteristics (cell shape, gram testing) [16]. QTS-24 kits were used to determine the carbon/nitrogen (C/N) source utilization pattern of bacterial isolates. Isolated bacterial strains were tested for their halotolerance abilities by growing them in LB media supplemented with $\mathrm{NaCl}(2 \%, 4 \%, 6 \%, 8 \%, 10 \%, 15 \%)$ [16].

\subsection{Plant Growth-Promoting (PGP) Traits}

All the bacterial isolates were evaluated for their PGP characteristics. Phosphorous (P) solubilization was done by spot inoculating overnight grown cultures onto pikovaskaya's agar (Sigma) containing tri-calcium phosphate as an insoluble P source [17]. The colonies, which produced clearing zones in the pikovaskaya's agar plates, were considered positive for phosphorous solubilization. Total solubilized phosphate was measured by using the phosphomolybdate blue color method [18]. Modified pikovaskaya's broth medium was inoculated with each strain and incubated at $30{ }^{\circ} \mathrm{C}$ for 5 days. The cultures were centrifuged at $6000 \mathrm{rpm}$ for $15 \mathrm{~min}$. The supernatant $(500 \mu \mathrm{L})$ was mixed with $40 \mu \mathrm{L}$ of 2,4-dinitrophenol, after which $20 \mu \mathrm{L}$ of dilute sulfuric acid were added, followed by $5 \mathrm{~mL}$ of chromogenic reagent, and the volume was diluted to $50 \mathrm{~mL}$ using sterilized water and absorbance was recorded at $680 \mathrm{~nm}$. Siderophore production was done by spot inoculation on chrome azurol S (CAS) media as described by Schwyn and Neilands [19]. Bacterial strains were spot inoculated on petri plates containing CAS media. An uninoculated plate was taken as the control. After inoculation, plates were incubated at $28{ }^{\circ} \mathrm{C}$ for 5-7 days and observed for the formation of an orange zone around the bacterial colonies. Bacterial isolates were tested for hydrogen cyanide production through the method of Lorck [20]. Bacterial strains were streaked on nutrient agar medium (pre-soaked in 0.5\% picric acid and $2 \%$ sodium carbonate $w / v)$, supplemented with glycine $(4.4 \mathrm{~g} / \mathrm{L})$. Plates were sealed with parafilm paper and incubated at $30^{\circ} \mathrm{C}$ for 4 days. The appearance of an orange or red color indicates the production of hydrogen cyanide.

\subsection{Germination Experiment}

This experiment was carried in the Plant Physiology Laboratory of PMAS-Arid Agriculture University. Seeds of the wheat variety (Galaxy 2013) obtained from the National Agricultural Research Centre, Islamabad were surface sterilized by treatment with sodium hypochlorite $(1 \%)$ solution for $5 \mathrm{~min}$. After, seeds were successively washed with distilled water. All the isolated strains were tested for germination attributes. Sterilized seeds of wheat were placed in pre-soaked filter paper in Petri dishes. $\mathrm{NaCl}$ solution $(50 \mathrm{mM}, 100 \mathrm{mM}, 150 \mathrm{mM}, 200 \mathrm{mM}$ ) was given instead of normal water. The germination experiment was carried out under laboratory conditions with an average photoperiod of $10 \mathrm{~h}$ day $/ 14 \mathrm{~h}$ night at $24{ }^{\circ} \mathrm{C}$. The germination percentage, seedling vigor index, and promptness index were measured for each treatment [21]. Four strains were selected for further analysis, based upon their efficacy in the germination experiment and were labeled as $\mathrm{SR}_{1}, \mathrm{SR}_{2}, \mathrm{SR}_{3}$, and $\mathrm{SR}_{4}$.

\subsection{Production of Osmolytes}

To analyze proline and total soluble sugars, the supernatant of PGPR grown in LB broth supplemented with $\mathrm{NaCl}$ concentrations $(0 \%, 2 \%, 4 \%, 6 \%, 8 \%$, and $10 \%)$ were analyzed as described by Upadhyay et al. [22]. For the estimation of the proline contents, centrifugation of the culture broth was done at $1000 \times g$ for $10 \mathrm{~min}$ and the supernatant was used for estimation. Total soluble sugar (TSS) was estimated by mixing $1 \mathrm{~mL}$ of supernatant with $4 \mathrm{~mL}$ of anthrone reagent, the mixture was later boiled in a water bath for $8 \mathrm{~min}$. After rapid cooling, the optical density was measured at $630 \mathrm{~nm}$, and the amount of TSS was calculated from a standard curve.

\subsection{Phytohormone Production}

The ability of four selected halotolerant strains to produce phytohormones (IAA, GA, CK, ABA) in the culture media was measured by the method of Tien et al. [23]. The extraction of hormones was 
done by centrifugation of bacterial cultures at 10,000 rpm for $15 \mathrm{~min}$. For adjustment of the $\mathrm{pH}(2.8)$, $1 \mathrm{~N} \mathrm{HCl}$ was used. In the next step, an equal volume of ethyl acetate was used for hormone extraction. The resulting solution was evaporated at $35^{\circ} \mathrm{C}$ and the end residue was mixed in $1500 \mu \mathrm{L}$ of methanol. Finally, the samples were run on High Performance Liquid Chromatography (HPLC) (Agilent 1100), which had a C18 column $(39 \times 300 \mathrm{~mm})$ and a UV detector. For standardization of HPLC, pure grade chemicals of the hormones IAA, CK, GA, and ABA (Sigma Chemical Co., St. Louis, MO, USA) were dissolved in HPLC-grade methanol and were used. The wavelength used for the detection was as follows: IAA at $280 \mathrm{~nm}$; and GA, CK, and ABA at $254 \mathrm{~nm}$. The phytohormone content of LB media, without inoculum, was used to normalize the data.

\subsection{S rRNA Gene Sequence and Phylogenetic Analysis}

DNA was extracted from pure LB broth cultures as described by Chen and Kuo [24]. Amplification of genomic DNA of isolated strains was done as described by Weisburg et al. [25]. The PCR was carried out for amplification of the 16S rRNA gene with universal nucleotide sequence forward primer (fd1) AGAGTTTGATCCTGGCTCAG, and reverse primer (rd1) (AAGGAGGTGATCCAGCC). DNA was purified and sequenced on an automated sequencer by gel purification kits (JET quick, Gel Extraction Spin Kit, GENOMED). The strains were identified by using a nearly complete sequence of the $16 \mathrm{~s}$ rRNA gene on (BLAST) NCBI by comparing sequence homology with other strains. The maximum parsimony method was used for the analysis of evolutionary linkages [26].

\subsection{Plant Inoculation}

A pot experiment was conducted in the greenhouse of the Botany Department, PMAS-AAUR, Rawalpindi. A complete randomized design was applied with three replications. Each selected halotolerant strain was grown overnight in LB media. To obtain a cell pellet, the supernatant was discarded after centrifugation at $3000 \mathrm{rpm}$ for $3 \mathrm{~min}$. The cell pellet was washed three times with autoclaved water and the absorbance was recorded with a spectrophotometer at $600 \mathrm{~nm}$ to obtain the desired concentration, i.e., $10^{7} \mathrm{CFU}$. Ten sterilized seeds were sown in each pot (containing $10 \mathrm{~kg}$ of soil) in the greenhouse with the day $10 \mathrm{~h} / 14 \mathrm{~h}$ night at a temperature of $21 / 15^{\circ} \mathrm{C}$. Soil moisture was maintained at $15 \pm 1 \%$. Four strains and their consortium were evaluated under two treatment controls and $150 \mathrm{mM} \mathrm{NaCl}$ stress. The salt level was maintained with EC of $4.0 \mathrm{dS} \mathrm{m}^{-1}$ (first irrigation) or $8.5 \mathrm{dS} \mathrm{m}^{-1}$ (second irrigation). Plants were harvested after 45 days of sowing. Fresh and dry biomass was recorded. Leaf area was measured with the help of a leaf area meter. All the samples were collected in zipper bags and stored at $-20^{\circ} \mathrm{C}$ freezer for further biochemical assays. The percent of water content was determined by measuring the ratio between the fresh and dry weight of the upper fully developed leaf by using the following formula [27]:

$$
\mathrm{RWC}=[\mathrm{FW}-\mathrm{DW}] /[\mathrm{TW}-\mathrm{DW}] \times 100
$$

\subsection{Electrolyte Leakage (\%)}

Electrolyte leakage was determined by the method of Srairam [28]. Leaf discs weighing $0.1 \mathrm{~g}$ were heated in $10 \mathrm{~mL}$ of distilled water for $30 \mathrm{~min}$ at $40^{\circ} \mathrm{C}$ and the electrical conductivity (C1) was recorded. The same discs were then heated at $100{ }^{\circ} \mathrm{C}$ and again electrical conductivity (C2) was recorded. Whereas, calculations were done by the following formula:

$$
\mathrm{MSI}=[1-(\mathrm{C} 1 / \mathrm{C} 2)] \times 100
$$




\subsection{Chlorophyll and Carotenoid Content}

Leaf chlorophyll a, b, total chlorophyll, and carotenoid contents were estimated by the method of Arnon [29]. Fresh leaves $(0.5 \mathrm{~g})$ were ground in $10 \mathrm{~mL}$ of $80 \%$ acetone. The readings of the filtrate were measured at $470 \mathrm{~nm}, 663 \mathrm{~nm}$, and $645 \mathrm{~nm}$. Calculations were done by the following equations:

$$
\begin{gathered}
\text { Chla }(\mathrm{mg} / \mathrm{g})=\left[12.7 \mathrm{~A}_{663}-2.69 \mathrm{~A}_{645}\right](v / w) \\
\text { Chlb }(\mathrm{mg} / \mathrm{g})=\left[22.9 \mathrm{~A}_{645}-4.68 \mathrm{~A}_{663}\right](v / w) \\
\text { Total chlorophyll }(\mathrm{mg} / \mathrm{g})=\left[\left(20.2 \mathrm{~A}_{645}+8.02 \mathrm{~A}_{663}\right) v / w\right] \\
\text { Carotenoids content }(\mathrm{mg} / \mathrm{g})=\left(1000 \mathrm{~A}_{470}-1.8 \mathrm{Chl}_{\mathrm{a}}-85.02 \mathrm{Chl}_{\mathrm{b}}\right) / 198
\end{gathered}
$$

where $\mathrm{A}$ is the optical density at a specific wavelength.

\subsection{Proline Content}

Proline contents were determined by following the protocols of Bates [30]. Fresh leaves ( $0.5 \mathrm{~g})$ were homogenized with $10 \mathrm{~mL}$ of sulfosalicylic acid (3.0\%). The solution was filtered, and the filtrate was mixed with equal amounts of glacial acetic acid and ninhydrin reagent. The mixture was heated for $1 \mathrm{~h}$ in a water bath at $90^{\circ} \mathrm{C}$ and the reaction was stopped by transferring the mixture to ice. Toluene $(1 \mathrm{~mL})$ was added to the mixture and the solution was mixed and the solution separated into two layers. The upper layer was isolated in separate test tubes and the reading was measured at $520 \mathrm{~nm}$. Proline was determined as follows:

$$
\text { Proline }=(\text { Reading of sample } \times \text { Diluted concentration } \times \mathrm{K} \text { value }) / \text { material weight }
$$

\subsection{Total Soluble Sugar and Amino Acid}

Soluble sugars were estimated after the method of Dubois et al. [31]. Ground plant tissue $(0.1 \mathrm{~g})$ was mixed with $3 \mathrm{~mL}$ of $80 \%$ methanol. The solution was heated in a water bath for $30 \mathrm{~min}$ at $70{ }^{\circ} \mathrm{C}$. An equal volume of extract $(0.5 \mathrm{~mL})$ and $5 \%$ phenol was mixed with concentrated sulphuric acid $(1.5 \mathrm{~mL})$ and was again incubated in the dark for $30 \mathrm{~min}$. The absorbance of the sample was checked at $490 \mathrm{~nm}$ and the calculations were done by applying the following formula:

$$
\text { Sugar }(\mu \mathrm{g} / \mathrm{mL})=\text { Absorbance of sample } \times \text { Dilution factor } \times \mathrm{K} \text { value }
$$

Fresh tissue in grams.

The standard curve was prepared for glucose solution, which was used for the determination of the amount of sugar, expressed in $\mathrm{mg} \mathrm{g}^{-1} \mathrm{fw}^{-1}$.

The Ninhydrin method was used for the determination of free amino acids [32]. Leaf extract $(1 \mathrm{~mL})$ was mixed with the same volume of $0.2 \mathrm{M}$ citrate buffer ( $\mathrm{pH}-5)$ and $80 \%$ ethanol, and $2 \mathrm{~mL}$ of the ninhydrin reagent. The absorbance of the reaction mixture was taken to $570 \mathrm{~nm}$. Amino acids were computed with the equation:

Amino acids $=$ Absorption $\times$ volume $\times$ Diluted concentration/Sample weight $\times 1000$.

The amino acid, leucine, was used for preparing the standard curve, and results were expressed in $\mathrm{mg}$ of amino acid per $\mathrm{g}$ of dry tissue.

\subsection{Total Protein Content}

The concentration of protein was quantified by the Bradford assay [33]. Bovine serum albumin was used as a standard. Proteins were extracted by dissolving $0.2 \mathrm{~g}$ of leaf samples in $4 \mathrm{~mL}$ of sodium 
phosphate buffer ( $\mathrm{pH} 7$ ), and $0.5 \mathrm{~mL}$ of the extract was mixed with $3 \mathrm{~mL}$ of Comassive bio red dye. The optical density of the solution was measured at $595 \mathrm{~nm}$. Protein was determined by:

Protein $=$ Reading of extract $\times$ Diluted concentration $\times$ value of $\mathrm{K} /$ sample weight

\subsection{Antioxidant Enzyme Assay}

Enzyme extract was prepared by grinding one gram of leaf in liquid nitrogen. The obtained powder was added in $10 \mathrm{~mL}$ of $50 \mathrm{mM}$ phosphate buffer ( $\mathrm{pH}$ 7.0) and was mixed with $1 \mathrm{mM}$ Ethylene Diamine Tetra Acetic acid (EDTA) and 1\% polyvinylpyrrolidone (PVP). The whole mixture was centrifuged at $13,000 \times g$ for $20 \mathrm{~min}$ at $4{ }^{\circ} \mathrm{C}$. The supernatant was used for the enzyme assay.

The catalase (CAT) content was estimated by observing the degradation of $\mathrm{H}_{2} \mathrm{O}_{2}$ at $240 \mathrm{~nm}$ [34]. Catalase activity ( $\mathrm{U} \mathrm{mg}$ protein ${ }^{-1}$ ) was calculated from the molar absorption coefficient of $40 \mathrm{~mm}^{-1} \mathrm{~cm}^{-1}$ for $\mathrm{H}_{2} \mathrm{O}_{2}$. Peroxidase dismutase (POD) was determined by following the procedure of Rao [35]. The reaction mixture consisted of $10 \mu \mathrm{L}$ of crude enzyme extract, $20 \mu \mathrm{L}$ of $100 \mathrm{mM}$ guaiacol, $10 \mu \mathrm{L}$ of $100 \mathrm{mM} \mathrm{H}_{2} \mathrm{O}_{2}$, and $160 \mu \mathrm{L}$ of $50 \mathrm{mM}$ sodium acetate ( $\mathrm{pH}$ 5.0). Absorbance was recorded at $450 \mathrm{~nm}$.

Superoxide dismutase (SOD) activity was done by using the procedure of Giannopolitis and Ries [36]. The composition of the reaction mixture was $50 \mathrm{mM}$ sodium phosphate buffer ( $\mathrm{pH} 7.8$ ), $0.1 \mathrm{M}$ tris-HCL, $14 \mathrm{mM}$ methionine, $1.05 \mathrm{mM}$ riboflavin, 0.03\% TritonX-100, $50 \mathrm{mM}$ nitroblue tetrazolium chloride (NBT), $100 \mathrm{mM}$ EDTA, and $20 \mu \mathrm{L}$ enzyme extracts. After adding riboflavin, the glass tubes were illuminated for $5 \mathrm{~min}$, and reactions were stopped by turning off lights. The absorbance was recorded at $560 \mathrm{~nm}$.

\subsection{Statistical Analysis}

Three replicates were used for the mean and standard deviation values of the data. The obtained data were further analyzed by Duncan's multiple range tests using MSTAT-C version 1.4.2. The correlation coefficient of the data was done using the software Statistix version 8.1. Mean values were compared by the least significant difference (LSD) at $p \leq 0.05$ [37]. The heatmap for the correlation coefficient was prepared by using web tool clustvis (https://biit.cs.ut.ee/clustvis/).

\section{Results}

\subsection{Soil Analysis}

Analysis of the rhizospheric soil samples of all four plants showed the soil was sandy clay loam with an EC range of $0.76-0.85 \mathrm{dSm}^{-1}, \mathrm{pH}$ in the range of 7.99-8.12, high $\mathrm{Na} / \mathrm{K}$ ratio, and a low concentration of nutrients (Table 1 ). 
Table 1. Physiochemical properties of the rhizosphere soil and rhizobacterial population.

\begin{tabular}{|c|c|c|c|c|c|c|c|c|c|c|c|c|c|c|c|}
\hline \multirow{2}{*}{$\begin{array}{l}\text { Host Plant } \\
\text { Species }\end{array}$} & \multirow{2}{*}{$\mathrm{pH}$} & \multirow{2}{*}{$\begin{array}{c}\mathrm{EC} \\
\left(\mathrm{dSm}^{-1}\right)\end{array}$} & \multirow{2}{*}{ Soil Texture } & \multirow{2}{*}{$\begin{array}{c}\text { SAR } \\
(\mathrm{mmol} / \mathrm{L})\end{array}$} & \multirow{2}{*}{ OC (\%) } & \multicolumn{6}{|c|}{ Macronutrient (meq/L) } & \multicolumn{3}{|c|}{$\begin{array}{c}\text { Available } \\
\text { Nutrients (kg/ha) }\end{array}$} & \multirow{2}{*}{$\begin{array}{l}\text { PGPR Population } \\
\left(\mathrm{cfu} \times 10^{5} \mathrm{~g}^{-1} \text { of Soil }\right)\end{array}$} \\
\hline & & & & & & $\mathrm{CO}_{3}$ & $\mathrm{HCO}_{3}$ & $\mathrm{Cl}$ & $\mathrm{Ca}^{+}$ & $\mathrm{Na}^{+}$ & $\mathrm{K}^{+}$ & $\mathbf{N}$ & $\mathbf{P}$ & $\mathbf{K}$ & \\
\hline $\begin{array}{l}\text { Abutilom } \\
\text { bidiantum }\end{array}$ & 7.99 & 0.82 & $\begin{array}{l}\text { Sandy clay } \\
\text { loam }\end{array}$ & 39.6 & 0.72 & 3.9 & 15 & 50 & 3 & 82.95 & 0.3 & 240 & 200 & 320 & 69 \\
\hline $\begin{array}{l}\text { Maytenus } \\
\text { royleanus }\end{array}$ & 8.12 & 0.85 & $\begin{array}{l}\text { Sandy clay } \\
\text { loam }\end{array}$ & 40.3 & 0.54 & 4 & 14 & 48 & 2.5 & 80.6 & 0.4 & 238 & 196 & 325 & 64 \\
\hline Kallar grass & 7.80 & 0.76 & $\begin{array}{l}\text { Sandy clay } \\
\text { loam }\end{array}$ & 42.5 & 0.62 & 4.2 & 17 & 47 & 2.8 & 78.9 & 0.5 & 243 & 190 & 315 & 62 \\
\hline $\begin{array}{l}\text { Dedonia } \\
\text { viscoca }\end{array}$ & 8.01 & 0.79 & $\begin{array}{l}\text { Sandy clay } \\
\text { loam }\end{array}$ & 38.1 & 0.64 & 4.5 & 17.5 & 48 & 3.1 & 81.2 & 0.4 & 237 & 205 & 330 & 65 \\
\hline
\end{tabular}




\subsection{Isolation and Screening of Salt-Tolerant PGPR Strains}

A total of 50 isolates were obtained from the rhizospheric soil of four halophytic plants. Among all isolates, $90 \%$ of colonies were round, creamy, and had entire margins (Supplementary Materials Table S1). Further, $78 \%$ of isolates were Gram-negative and rod-shaped (Supplementary Materials Table S2).

In the halotolerant assay, $70 \%$ of strains were able to grow up to $6 \%, 20 \%$ strains showed tolerance at $10 \%$, while four strains $\mathrm{SR}_{1}, \mathrm{SR}_{2}, \mathrm{SR}_{3}$, and $\mathrm{SR}_{4}$ were able to grow at $15 \% \mathrm{NaCl}$ (Supplementary Materials Table S2). These four strains also showed positive results for phosphorous solubilization, hydrogen cyanide, and siderophore production (Supplementary Materials Table S3).

\subsection{Effect of Bacterial Isolates on Germination of Wheat}

Salt stress resulted in a considerable reduction in the germination parameters of the wheat seeds. Under salt-stressed conditions, the seedling vigor index and germination index showed a $12.5 \%$ and $31 \%$ decrease compared to the control. Though most of the strains showed a significant increase in seed germination, four strains $\mathrm{SR}_{1}, \mathrm{SR}_{2}, \mathrm{SR}_{3}$, and $\mathrm{SR}_{4}$ showed prominent results $(14.28 \%, 35 \%, 42 \%$, and 55\%), respectively, as compared to the non-inoculated control under the salt stress condition (Supplementary Materials Table S4).

\subsection{Identification of Isolates}

Initially, the four strains were identified based on the $\mathrm{C} / \mathrm{N}$ source utilization pattern (Supplementary Materials Table S5). Molecular identification of the screened halotolerant strains was done based on $16 \mathrm{~S}$ rRNA sequences and on the comparison of the 1500-bp sequence of 16S rRNA gene subjected to BLAST to confirm the relatedness with other bacterial strains. The isolate $\mathrm{SR}_{1}$ (1485 base pair) was closely related (98\% nucleotide identity) to sequences of bacteria annotated as Bacillus strain JQ 926435 in the GenBank database. The sequence of $\mathrm{SR}_{2}$ (1480 base pairs) was 99\% identical to Azospirillum brasilense DQ 288686.1, $\mathrm{SR}_{3}$ (1482 base pairs), and 96\% identical to strain Azospirillum lipoferum accession no. M. 5906.1. Furthermore, the isolated strain $\mathrm{SR}_{4}$ showed a $99 \%$ homology with Pseudomonas stutzeri JQ 926435. The accession numbers of the identified strains were obtained from NCBI and are given in Table 2.

Table 2. Molecular identification of the isolates based on partial $16 \mathrm{~S}$ rDNA analysis.

\begin{tabular}{cccccc}
\hline No & Isolates & Base Pair Length & Similarity (\%) & Strain Identification & Accession No. \\
\hline 1 & $\mathrm{SR}_{1}$ & 1485 & $98 \%$ & Bacillus sp. & KF719179 \\
\hline 2 & $\mathrm{SR}_{2}$ & 1480 & $99 \%$ & Azospirillum brasilense & KJ194586 \\
\hline 3 & $\mathrm{SR}_{3}$ & 1482 & $96 \%$ & Azospirillum lipoferum & $\mathrm{KJ} 434039$ \\
\hline 4 & $\mathrm{SR}_{4}$ & 1263 & $99 \%$ & Pseudomonas stutzeri & KJ685889 \\
\hline
\end{tabular}

Further phylogenetic analysis of the identified bacteria was conducted in MEGA4 software to determine their affiliation [38]. The evolutionary history was inferred using the maximum parsimony method [26]. The results are shown in Supplementary Materials Figures S1-S4.

\subsection{Production of Phytohormones}

Based on the halotolerance assays, PGP traits, and germination assay results, four isolates were selected for further analysis. All the halotolerant PGPR strains showed the production of phytohormones in liquid culture (Figure 1). Halotolerant PGPR strains were able to produce IAA (0.5-2.1 $\left.\mu \mathrm{g} \mathrm{mL}^{-1}\right)$, gibberellic acid (1.5-2.5 $\left.\mathrm{g} \mathrm{mL}^{-1}\right), \mathrm{CK}\left(0.39-0.64 \mu \mathrm{g} \mathrm{mL} \mathrm{m}^{-1}\right)$, and ABA (1.9-3.4 $\mu \mathrm{g} \mathrm{mL}^{-1}$ ). The PGPR strains $\mathrm{SR}_{2}$ and $\mathrm{SR}_{3}$ produced higher concentrations of phytohormones than those of $\mathrm{SR}_{1}$ and $\mathrm{SR}_{4}$; however, the bacterial consortium produced maximum concentrations of IAA $\left(2.1 \mu \mathrm{g} \mathrm{mL}^{-1}\right)$, gibberellic acid $\left(2.5 \mu \mathrm{g} \mathrm{mL} \mathrm{mL}^{-1}\right), \mathrm{CK}\left(0.64 \mu \mathrm{g} \mathrm{mL}{ }^{-1}\right)$, and ABA $\left(3.4 \mu \mathrm{gL}^{-1}\right)$. 


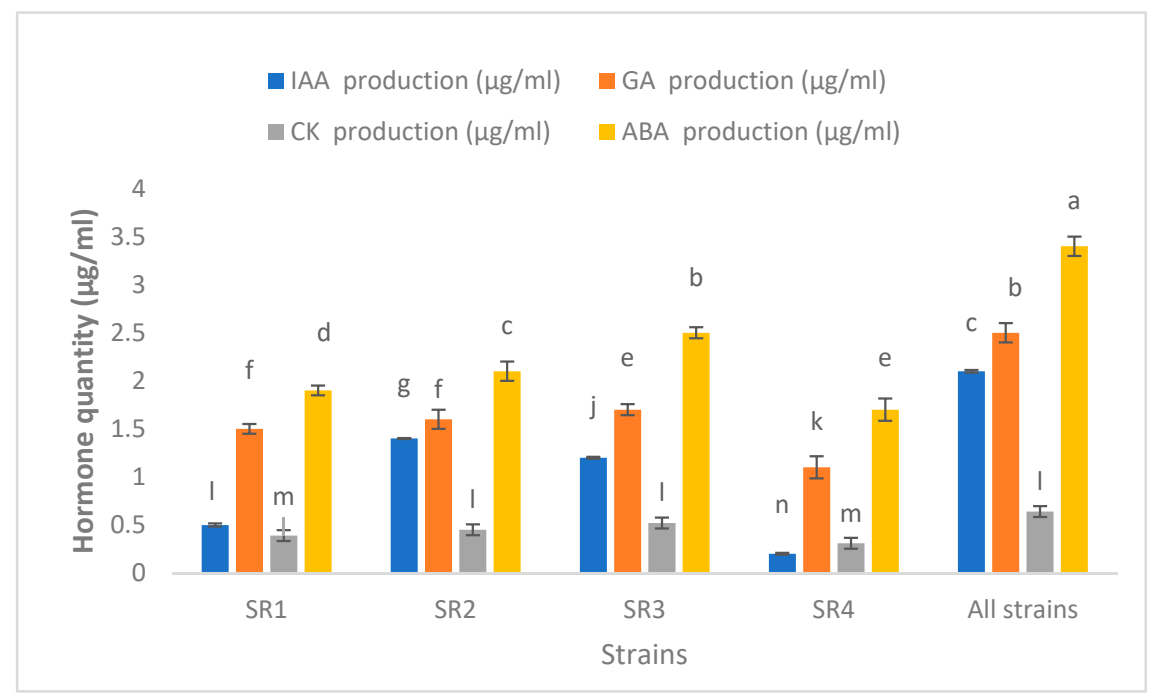

Figure 1. Production of phytohormones (Indole Acetic Acid (IAA), Gibberellic Acid (GA), Cytokinin (CK), and Abscisic Acid (ABA) by PGPR strains and their consortium in culture media. $\left(\mathrm{SR}_{1}\right.$ : Inocualted with Bacillus sp; $\mathrm{SR}_{2}$ : Inocualted with Azospirillum brasilense; $\mathrm{SR}_{3}$ : Inocualted with Azospirillum lipoferum; $\mathrm{SR}_{4}$ : Inocualted with Pseudomonas stutzeri; Consortium is a combination of all four strains Bacillus sp, Azospirillum brasilense, Azospirillum lipoferum, Pseudomonas stutzeri). This data displays the means and standard deviation $(n=3)$. Different letters show significant differences between treatments $(p<0.05)$.

\subsection{Production of Compatible Solutes}

A considerable amount of proline was produced by all the screened halotolerant strains when subjected to different salinity levels. Production of proline by $\mathrm{SR}_{2}$ and $\mathrm{SR}_{3}$ was the highest in the $10 \%$ saline condition than the control. The maximum amount of proline $\left(12.1 \mu \mathrm{g} \mathrm{mg}^{-1}\right)$ was produced by the bacterial consortium, which was $23 \%$ greater than $\mathrm{SR}_{2}$ and $\mathrm{SR}_{3}$. For the carbohydrate contents, a significant amount of soluble sugars was recorded by all the strains (Figure 2). The production of soluble sugars was more pronounced at different salinity levels than the control. The bacterial strains $\mathrm{SR}_{2}$ and $\mathrm{SR}_{3}$ produced a greater amount of $\left(89-111 \mu \mathrm{g} \mathrm{mg}^{-1}\right)$ soluble sugar as compared to the control, but the consortium of bacterial isolates recorded the maximum values at $10 \% \mathrm{NaCl}\left(222 \mu \mathrm{g} \mathrm{mg}^{-1}\right)$ (Figure 3).

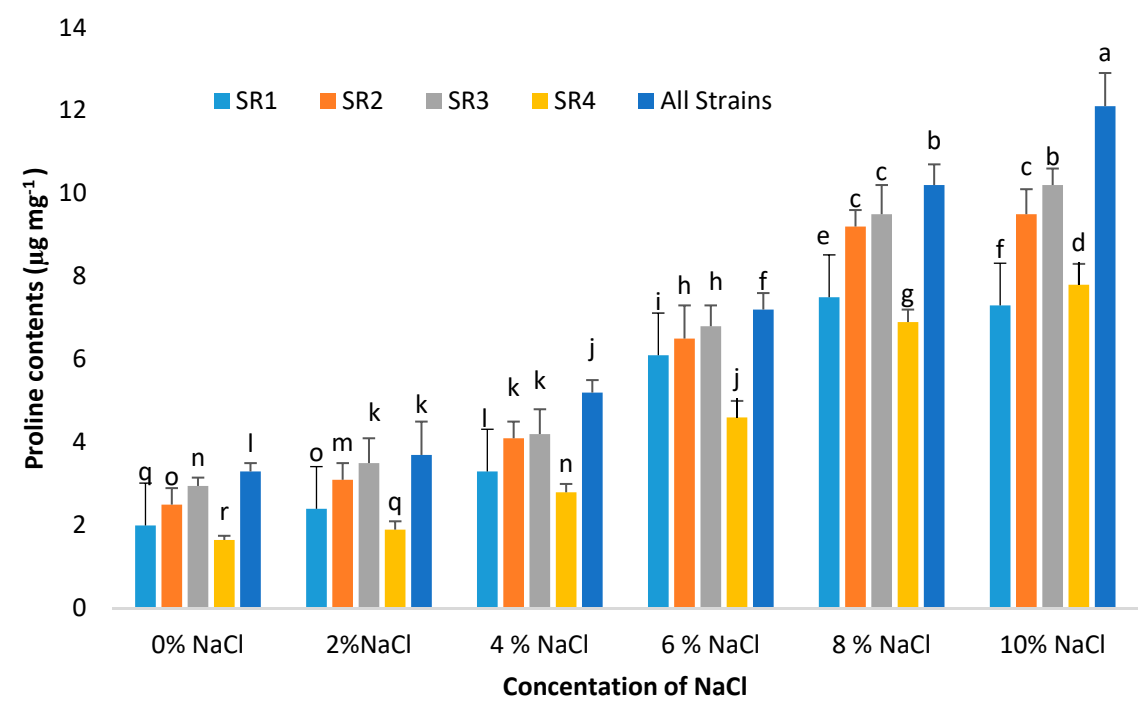

Figure 2. Production of proline by PGPR strains and their consortium in culture media supplemented with different concentrations of $\mathrm{NaCl}(2 \%, 4 \%, 6 \%, 8 \%$, and $10 \%)$. The treatment details are the same as in Table 3. This data displays the means and standard deviation $(n=3)$. Different letters show significant differences between treatments $(p<0.05)$. 


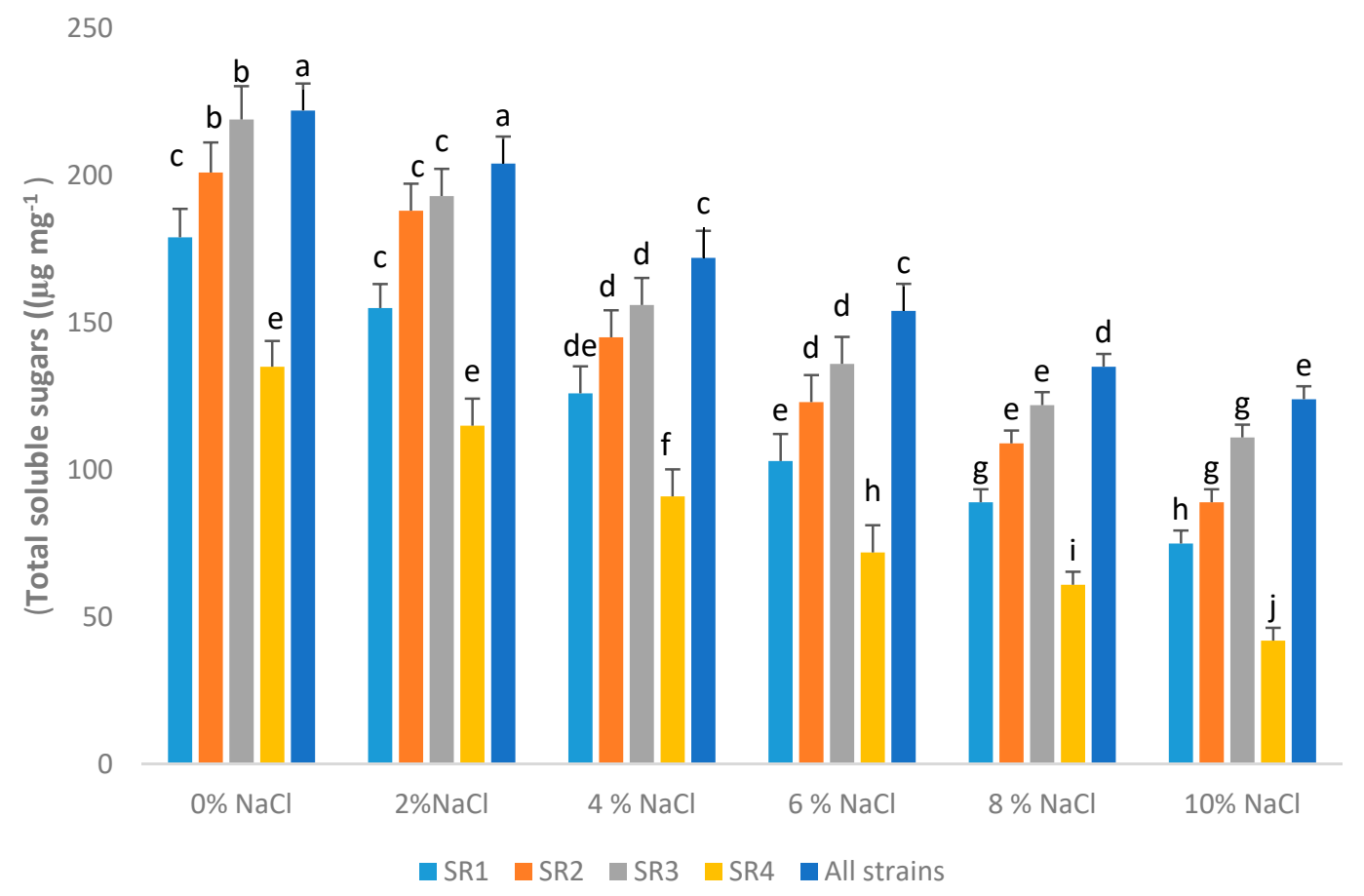

Figure 3. Production of total soluble sugar by PGPR strains and their consortium in culture media supplemented with different concentrations of $\mathrm{NaCl}(2 \%, 4 \%, 6 \%, 8 \%$, and $10 \%)$. The treatment details are the same as in Table 3. This data displays the means and standard deviation $(n=3)$. Different letters show significant differences between treatments $(p<0.05)$.

\subsection{Effect of PGPR Inoculation on the Biomass of Wheat (Triticum aestivum L.) Plants Grown under Salinity Stress}

The overall decrease of 30\% in the plant biomass of wheat plants was observed due to salt stress. However, the bacterial isolates exerted a significant positive influence on wheat growth and resulted in an increase in the biomass of plants in the control and stressed conditions, respectively. The relative increase in the fresh and dry biomass due to bacterial isolates ranged between $39 \%$ and $67 \%$ as compared to the uninoculated plants under saline conditions.

The best results were obtained when plants were inoculated with a consortium of all four isolated strains, which caused an increase of $93 \%$ in stress and $60 \%$ in controlled conditions. Moreover, pronounced results were also encountered for dry biomass, when plants were inoculated with a consortium, which resulted in an increase of $65.4 \%$ in salt stress and $78.7 \%$ in control conditions (Table 3).

Table 3. Effect of inoculation of halotolerant PGPR on the fresh and dry biomass and leaf area of wheat plants grown under salinity stress.

\begin{tabular}{ccccccc}
\hline Treatments & \multicolumn{2}{c}{ Fresh Biomass $\mathbf{( g )}$} & \multicolumn{2}{c}{ Dry Biomass $\mathbf{( g )}$} & \multicolumn{2}{c}{ Leaf Area $\left.\mathbf{( c m}^{\mathbf{2}}\right)$} \\
& $\mathbf{0 ~} \mathbf{~ m M}$ & $\mathbf{1 5 0} \mathbf{~ m M}$ & $\mathbf{0 ~} \mathbf{~ m M}$ & $\mathbf{1 5 0} \mathbf{~ m M}$ & $\mathbf{0 ~} \mathbf{~ M M}$ & $\mathbf{1 5 0} \mathbf{~ m M}$ \\
\hline Control & $10 \pm 1 \mathrm{~g}$ & $7.3 \pm 0.4 \mathrm{i}$ & $3.3 \pm 0.1 \mathrm{c}$ & $2.2 \pm 0.04 \mathrm{~d}$ & $140 \pm 12 \mathrm{e}$ & $120 \pm 17 \mathrm{f}$ \\
$\mathrm{SR}_{1}$ & $11 \pm 0.5 \mathrm{f}$ & $8.2 \pm 0.9 \mathrm{~h}$ & $3.5 \pm 0.4 \mathrm{c}$ & $2.8 \pm 0.06 \mathrm{~d}$ & $150 \pm 15 \mathrm{~d}$ & $130 \pm 14 \mathrm{f}$ \\
$\mathrm{SR}_{2}$ & $13.2 \pm 0.9 \mathrm{e}$ & $10.3 \pm 0.7 \mathrm{~g}$ & $4.1 \pm 0.1 \mathrm{~b}$ & $3.5 \pm 0.09 \mathrm{c}$ & $167 \pm 12 \mathrm{c}$ & $140 \pm 24 \mathrm{e}$ \\
$\mathrm{SR}_{3}$ & $16.9 \pm 1.2 \mathrm{~b}$ & $13.9 \pm 1.4 \mathrm{~d}$ & $4.7 \pm 0.5 \mathrm{~b}$ & $3.8 \pm 0.03 \mathrm{c}$ & $177 \pm 17 \mathrm{~b}$ & $147 \pm 17 \mathrm{e}$ \\
$\mathrm{SR}_{4}$ & $11.50 .98 \mathrm{f}$ & $7.8 \pm 0.54 \mathrm{i}$ & $3.6 \pm 0.5 \mathrm{c}$ & $3.0 \pm 0.08 \mathrm{~d}$ & $160 \pm 14 \mathrm{c}$ & $135 \pm 12 \mathrm{f}$ \\
Consortium & $20.3 \pm 1.8 \mathrm{a}$ & $14.1 \pm 1.9 \mathrm{c}$ & $5.9 \pm 0.2 \mathrm{a}$ & $4.3 \pm 0.03 \mathrm{~b}$ & $186 \pm 19 \mathrm{a}$ & $152 \pm 13 \mathrm{~d}$ \\
\hline
\end{tabular}

This data displays the means and standard deviation $(n=3)$. Different letters show significant differences $(p<0.05)$. $\left(\mathrm{SR}_{1}\right.$ : Inocualted with Bacillus sp; $\mathrm{SR}_{2}$ : Inocualted with Azospirillum brasilense; $\mathrm{SR}_{3}$ : Inocualted with Azospirillum lipoferum; $\mathrm{SR}_{4}$ : Inocualted with Pseudomonas stutzeri; Consortium is a combination of all four strains Bacillus sp, Azospirillum brasilense, Azospirillum lipoferum, Pseudomonas stutzeri). 


\subsection{Effect on the Membrane Stability Index and Water Content}

Results of the percent electrolytic leakage showed that the inoculation remains significant under stress as well as normal conditions However, co-inoculation with bacterial consortium successfully decreased (34\%) the ionic discharge at the $150 \mathrm{mM} \mathrm{NaCl}$ level compared to the control (Table 4). Furthermore, the percent of water content showed a significant reduction of $33 \%$ in wheat plants under salt stress as compared to the uninoculated control plants. More pronounced results were obtained with $\mathrm{SR}_{2}$ and $\mathrm{SR}_{3}$, causing an increase of $10.5 \%$ and $17.54 \%$ in the stress condition. The consortiuminoculated plants recorded the maximum amount of water of $21 \%$ and $17.64 \%$ in the stress and control conditions. A similar trend was observed by $\mathrm{SR}_{1}$ and $\mathrm{SR}_{4}$ (Table 4).

Table 4. Effect of inoculation of halotolerant PGPR strains on the leaf water content and electrolyte leakage of wheat plants grown under salinity stress.

\begin{tabular}{ccccc}
\hline Treatments & \multicolumn{2}{c}{ Percent Water Content } & \multicolumn{2}{c}{ Electrolyte Leakage (\%) } \\
\hline & $0 \mathrm{mM}$ & $150 \mathrm{mM}$ & $0 \mathrm{mM}$ & $150 \mathrm{mM}$ \\
Control & $85 \pm 1.5 \mathrm{~b}$ & $57 \pm 0.9 \mathrm{e}$ & $33 \pm 0.4 \mathrm{~d}$ & $55 \pm 0.5 \mathrm{a}$ \\
$\mathrm{SR}_{1}$ & $86.3 \pm 1.6 \mathrm{~b}$ & $60 \pm 1 \mathrm{~d}$ & $30 \pm 0.3 \mathrm{~d}$ & $50 \pm 0.45 \mathrm{a}$ \\
$\mathrm{SR}_{2}$ & $89 \pm 1.9 \mathrm{~b}$ & $63 \pm 1.4 \mathrm{~d}$ & $26.2 \pm 0.25 \mathrm{e}$ & $41.3 \pm 0.33 \mathrm{c}$ \\
$\mathrm{SR}_{3}$ & $95 \pm 2.1 \mathrm{a}$ & $67 \pm 1.7 \mathrm{~d}$ & $25.7 \pm 0.4 \mathrm{e}$ & $42.08 \pm 0.11 \mathrm{c}$ \\
$\mathrm{SR}_{4}$ & $88.7 \pm 1.9 \mathrm{~b}$ & $61 \pm 1.15 \mathrm{~d}$ & $31.2 \pm 0.22 \mathrm{e}$ & $47.8 \pm 0.44 \mathrm{~b}$ \\
Consortium & $97 \pm 2.0 \mathrm{a}$ & $70 \pm 1.75 \mathrm{c}$ & $22.1 \pm 0.22 \mathrm{f}$ & $35.2 \pm 0.23 \mathrm{~d}$ \\
\hline
\end{tabular}

This data displays the means and standard deviation $(n=3)$. Different letters show significant differences $(p<0.05)$. Treatment details are the same as in Table 3.

\subsection{Chlorophyll Contents}

Salinity stress negatively affected the photosynthetic pigments of wheat plants. A considerable decrease of $30.4 \%, 22 \%$, and $25 \%$ was observed in chlorophyll a, b, and total chlorophyll. The response to the consortium was effective ( $p \leq 0.05$ ) and resulted in a $13.23 \%, 12.49 \%, 12.9 \%$, and $11.76 \%$ increase as compared to the control under salt-stress conditions (Table 5).

Table 5. Effect of halotolerant PGPR on the chlorophyll a, chlorophyll b, total chlorophyll, and carotenoid contents of wheat plants grown under salinity stress.

\begin{tabular}{ccccccccc}
\hline & $\begin{array}{c}\text { Chlorophyll a (mg/g Fresh } \\
\text { Weight) }\end{array}$ & \multicolumn{2}{c}{$\begin{array}{c}\text { Chlorophyll b (mg/g Fresh } \\
\text { Weight) }\end{array}$} & \multicolumn{2}{c}{$\begin{array}{c}\text { Total Chlorophyll (mg/g } \\
\text { Fresh Weight) }\end{array}$} & \multicolumn{2}{c}{$\begin{array}{c}\text { Carotenoid (mg/g Fresh } \\
\text { Weight) }\end{array}$} & \multicolumn{2}{c}{$\begin{array}{c}\text { Wha } \\
\text { Treatments }\end{array}$} & $0 \mathrm{mM}$ & $150 \mathrm{mM}$ & $0 \mathrm{mM}$ & $150 \mathrm{mM}$ & $0 \mathrm{mM}$ & $150 \mathrm{mM}$ & $0 \mathrm{mM}$ & $150 \mathrm{mM}$ \\
\hline Control & $1.06 \pm 0.01 \mathrm{~d}$ & $0.59 \pm 0.01 \mathrm{~h}$ & $0.27 \pm 0.02 \mathrm{~d}$ & $0.12 \pm 0.01 \mathrm{~h}$ & $1.18 \pm 0.10 \mathrm{e}$ & $0.86 \pm 0.05 \mathrm{f}$ & $46.9 \pm 0.1 \mathrm{f}$ & $65.8 \pm 0.15 \mathrm{k}$ \\
\hline $\mathrm{SR}_{1}$ & $1.13 \pm 0.03 \mathrm{~b}$ & $0.75 \pm 0.03 \mathrm{~g}$ & $0.29 \pm 0.04 \mathrm{~b}$ & $0.13 \pm 0.02 \mathrm{~g}$ & $1.26 \pm 0.09 \mathrm{~d}$ & $1.01 \pm 0.03 \mathrm{k}$ & $47.3 \pm 0.3 \mathrm{e}$ & $67.6 \pm 0.5 \mathrm{i}$ \\
\hline $\mathrm{SR}_{2}$ & $1.18 \pm 0.04 \mathrm{c}$ & $0.81 \pm 0.02 \mathrm{f}$ & $0.32 \pm 0.03 \mathrm{c}$ & $0.15 \pm 0.02 \mathrm{f}$ & $1.33 \pm 0.7 \mathrm{c}$ & $1.13 \pm 0.02 \mathrm{j}$ & $50.5 \pm 0.4 \mathrm{c}$ & $69.8 \pm 0.4 \mathrm{~h}$ \\
\hline $\mathrm{SR}_{3}$ & $1.2 \pm 0.05 \mathrm{c}$ & $0.85 \pm 0.04 \mathrm{~g}$ & $0.33 \pm 0.05 \mathrm{c}$ & $0.17 \pm 0.03 \mathrm{f}$ & $1.37 \pm 0.8 \mathrm{~b}$ & $1.18 \pm 0.04 \mathrm{k}$ & $51.1 \pm 0.2 \mathrm{~b}$ & $69.2 \pm 0.5 \mathrm{i}$ \\
\hline $\mathrm{SR}_{4}$ & $1.12 \pm 0.02 \mathrm{~b}$ & $0.77 \pm 0.03 \mathrm{~b}$ & $0.28 \pm 0.01 \mathrm{~b}$ & $0.13 \pm 0.02 \mathrm{~g}$ & $1.13 \pm 0.6 \mathrm{f}$ & $1.05 \pm 0.01 \mathrm{~d}$ & $48.2 \pm 0.4 \mathrm{~d}$ & $68.1 \pm 0.6 \mathrm{j}$ \\
\hline Consortium & $1.4 \pm 0.04 \mathrm{a}$ & $0.9 \pm 0.02 \mathrm{e}$ & $0.35 \pm 0.05 \mathrm{a}$ & $0.19 \pm 0.04 \mathrm{e}$ & $1.59 \pm 0.5 \mathrm{a}$ & $1.25 \pm 0.03 \mathrm{~h}$ & $52.8 \pm 0.6 \mathrm{a}$ & $70.4 \pm 0.8 \mathrm{~g}$ \\
\hline
\end{tabular}

This data displays the means and standard deviation $(n=3)$. Different letters show significant differences $(p<0.05)$. Treatment details are the same as in Table 3.

\subsection{Proline Contents}

Salinity stress increased proline accumulation in wheat plants. A considerable increase of $50 \%$ in the proline content of wheat plants was recorded in saline stress conditions as compared to their respective control. Inoculation with halotolerant PGPR increased the levels of proline in the leaves. All four inoculants increased the proline contents in the range of $18-36 \%$, respectively. The accumulation of proline was maximum in consortium-treated plants, with an increase of $46.67 \%$ under stress conditions (Table 6). 
Table 6. Effects of halotolerant PGPR on the total soluble sugar, amino acid, protein, and proline contents of wheat plants grown under salinity stress.

\begin{tabular}{|c|c|c|c|c|c|c|}
\hline \multirow[t]{2}{*}{ Treatments } & \multicolumn{2}{|c|}{ Total Soluble Sugar $\left(\mu \mathrm{g} \mathrm{g}^{-1} \mathrm{FW}\right)$} & \multicolumn{2}{|c|}{ Total Amino Acid $\left(\mu \mathrm{g} \mathrm{g}^{-1} \mathrm{FW}\right)$} & \multicolumn{2}{|c|}{ Proline ( $\left.\mu \mathrm{g} \mathrm{g}^{-1} \mathrm{FW}\right)$} \\
\hline & $0 \mathrm{mM}$ & $150 \mathrm{mM}$ & $0 \mathrm{mM}$ & $150 \mathrm{mM}$ & $0 \mathrm{mM}$ & $150 \mathrm{mM}$ \\
\hline Control & $27 \pm 2 \mathrm{~d}$ & $33 \pm 5 i$ & $330 \pm 10 g$ & $368 \pm 20 e$ & $40 \pm 03 d$ & $120 \pm 5 j$ \\
\hline $\mathrm{SR}_{1}$ & $29 \pm 3 d$ & $35 \pm 7 \mathrm{~h}$ & $345 \pm 12 \mathrm{f}$ & $379 \pm 17 e$ & $44 \pm 05 d$ & $128 \pm 6 \mathrm{i}$ \\
\hline $\mathrm{SR}_{2}$ & $31 \pm 5 c$ & $39 \pm 6 g$ & $360 \pm 15 e$ & $401 \pm 27 c$ & $51 \pm 3 c$ & $130 \pm 7 \mathrm{~g}$ \\
\hline $\mathrm{SR}_{3}$ & $33 \pm 3 c$ & $33 \pm 1.0 \mathrm{f}$ & $370 \pm 24 \mathrm{e}$ & $420 \pm 25 b$ & $54 \pm 3 b$ & $135 \pm 9 h$ \\
\hline $\mathrm{SR}_{4}$ & $29 \pm 4 d$ & $36 \pm 8 h$ & $350 \pm 12 f$ & $387 \pm 24.4 \mathrm{~d}$ & $43+3 c$ & $125 \pm 5 i$ \\
\hline Consortium & $39 \pm 5 c$ & $43 \pm 5 e$ & $381 \pm 10 \mathrm{~d}$ & $439 \pm 15 \mathrm{a}$ & $57 \pm 4 \mathrm{~b}$ & $145 \pm 7 f$ \\
\hline
\end{tabular}

This data displays the means and standard deviation $(n=3)$. Different letters show significant differences $(p<0.05)$. Treatment details are the same as in Table 3.

\subsection{Amino Acid Content}

The amino acid content was highest in the consortium of halotolerant PGPR strains, with an increase of $19.29 \%$ and $15.54 \%$ under salt stress and control conditions. Moreover, plants inoculated with $\mathrm{SR}_{2}$ and $\mathrm{SR}_{3}$ contained $10 \%$ and $14.1 \%$ greater concentrations of amino acids as compared to the uninoculated stressed plants (Table 6).

\subsection{Total Soluble Sugar}

Salinity stress produced a significant increase of $12.5 \%$ for the soluble sugar contents of wheat plants as compared to the control. The best outcomes were obtained when plants were inoculated with $\mathrm{SR}_{2}$ and $\mathrm{SR}_{3}$, which resulted in an increase of $9.52 \%$ and $15.87 \%$, respectively, under stress conditions. However, a more prominent effect was revealed with the inoculation of a consortium of strains, with an increase of $28.57 \%$ and $23.2 \%$, respectively, under the stress and control condition (Table 6).

\subsection{Antioxidants Enzyme Assay}

The antioxidant enzymes of the wheat plants showed a significant increase under salinity stress. Inoculation with all four halotolerant PGPR improved the production of antioxidant enzymes in plants. However, the best results were shown by the consortium of all strains. The consortium increased the superoxide dismutase activity by $21.4 \%$ as compared to stressed plants. Similarly, a significant increase of $16 \%$ in the catalase activity was recorded by the inoculation with the consortium. A significant increase of $34.4 \%$ in the peroxidase content of plants was recorded as compared to the control (Table 7).

Table 7. Effects of halotolerant PGPR on the antioxidant enzymes activity of wheat plants grown under salinity stress.

\begin{tabular}{|c|c|c|c|c|c|c|}
\hline \multirow[t]{2}{*}{ Treatments } & \multicolumn{2}{|c|}{$\begin{array}{c}\text { Superoxide Dismutase (EU } \\
\mathrm{mg}^{-1} \text { Protein) }\end{array}$} & \multicolumn{2}{|c|}{ Catalase (EU mg ${ }^{-1}$ Protein) } & \multicolumn{2}{|c|}{$\begin{array}{c}\text { Peroxidase (EU mg } \mathrm{mg}^{-1} \\
\text { Protein) }\end{array}$} \\
\hline & $0 \mathrm{mM}$ & $150 \mathrm{mM}$ & $0 \mathrm{mM}$ & $150 \mathrm{mM}$ & $0 \mathrm{mM}$ & $150 \mathrm{mM}$ \\
\hline Control & $0.74 \pm 0.06 \mathrm{k}$ & $1.83 \pm 0.02 f$ & $2.5 \pm 0.03 h$ & $4.13 \pm 0.02 \mathrm{f}$ & $144 \pm 3 f$ & $255 \pm 5 f$ \\
\hline $\mathrm{SR}_{1}$ & $0.76 \pm 0.04 j$ & $1.85 \pm 0.01 \mathrm{e}$ & $2.7 \pm 0.02 \mathrm{k}$ & $4.3 \pm 0.04 \mathrm{e}$ & $148 \pm 7 j$ & $260 \pm 4 d$ \\
\hline $\mathrm{SR}_{2}$ & $0.8 \pm 0.03 \mathrm{i}$ & $1.9 \pm 0.04 c$ & $3.01 \pm 0.04 \mathrm{i}$ & $4.7 \pm 0.09 c$ & $153 \pm 4 \mathrm{i}$ & $263 \pm 6 c$ \\
\hline $\mathrm{SR}_{3}$ & $0.82 \pm 0.05 h$ & $1.91 \pm 0.03 b$ & $3.12 \pm 0.05 h$ & $4.8 \pm 0.10 \mathrm{~b}$ & $155 \pm 6 h$ & $267 \pm 7 b$ \\
\hline $\mathrm{SR}_{4}$ & $0.78 \pm 0.3 \mathrm{j}$ & $1.85 \pm 0.4 \mathrm{~d}$ & $2.6 \pm 0.04 j$ & $4.5 \pm 0.05 d$ & $150 \pm 4 j$ & $257 \pm 5 d$ \\
\hline Consortium & $0.86 \pm 0.07 \mathrm{~g}$ & $1.96 \pm 0.05 a$ & $3.25 \pm 0.05 \mathrm{~g}$ & $5.05 \pm 0.04 a$ & $162 \pm 3 g$ & $270 \pm 6 a$ \\
\hline
\end{tabular}

This data displays the means and standard deviation $(n=3)$. Different letters show significant differences $(p<0.05)$. Treatment details are the same as in Table 3.

\subsection{Heatmap Responses of Pearson's Correlation Coefficient ( $r$ )}

From the heat map analysis, the data of the osmolyte production, electrolyte leakage, chlorophyll contents, antioxidant enzymes, and halotolerant PGPR showed positive correlations (Figure 4). A comparative analysis of the parameters related to salinity tolerance (presented by green boxes) 
showed that salinity tolerance had a positive correlation with amino acid, osmotic potential, soluble sugars, proline, SOD, POD, and CAT activities (Figure 5).
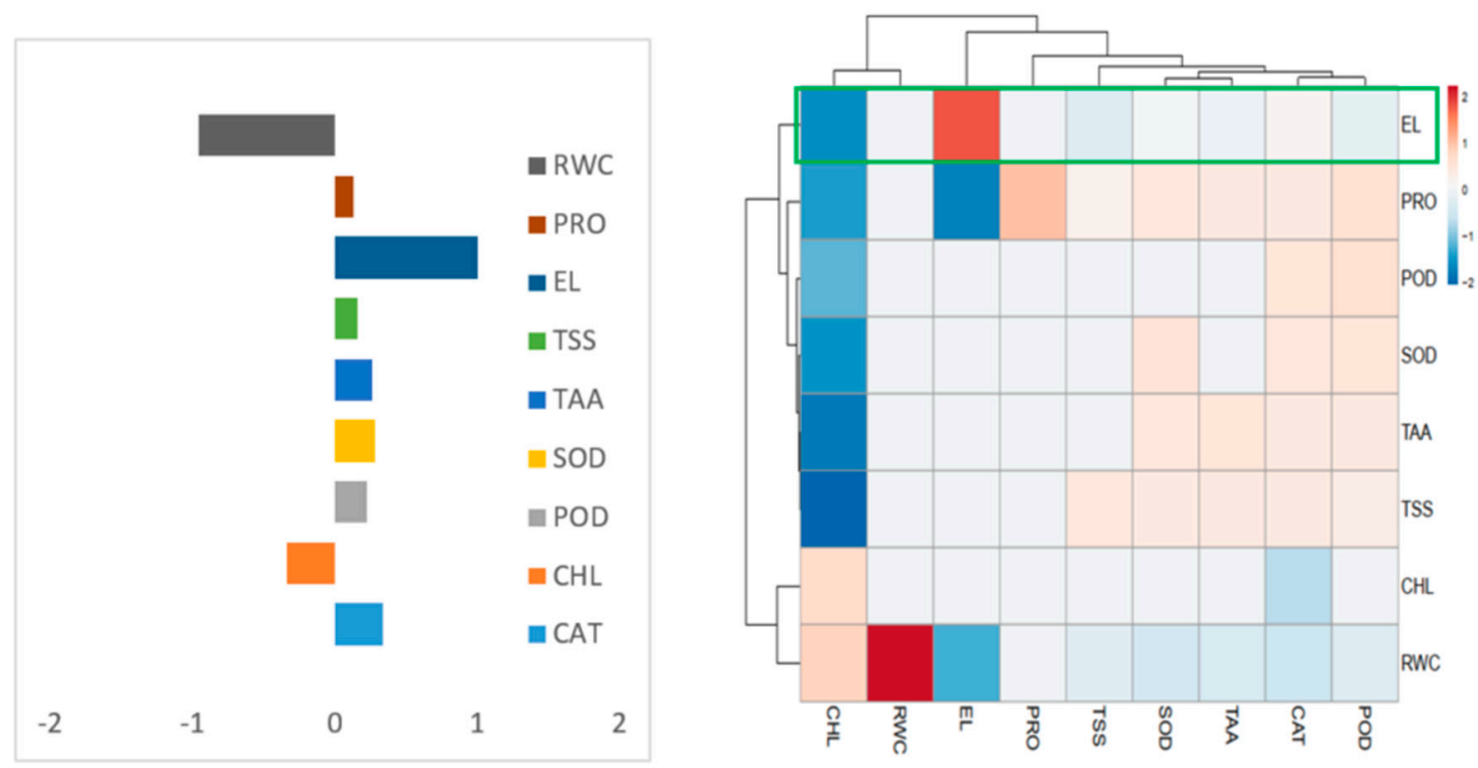

Figure 4. Heatmap of the correlation coefficient (r) for the antioxidant enzymes, stress determinants, and relative water content of wheat leaves treated with bacterial isolates and their consortium. Whereas, $\mathrm{EL}=$ Electrolyte leakage, Pro = Proline, $\mathrm{POD}=$ Peroxidase, $\mathrm{SOD}=$ Superoxide dismutase, $\mathrm{CHL}=$ Total chlorophyll, TAA $=$ Total amino acids, TSS $=$ Total soluble sugars, $\mathrm{RWC}=$ relative water content.

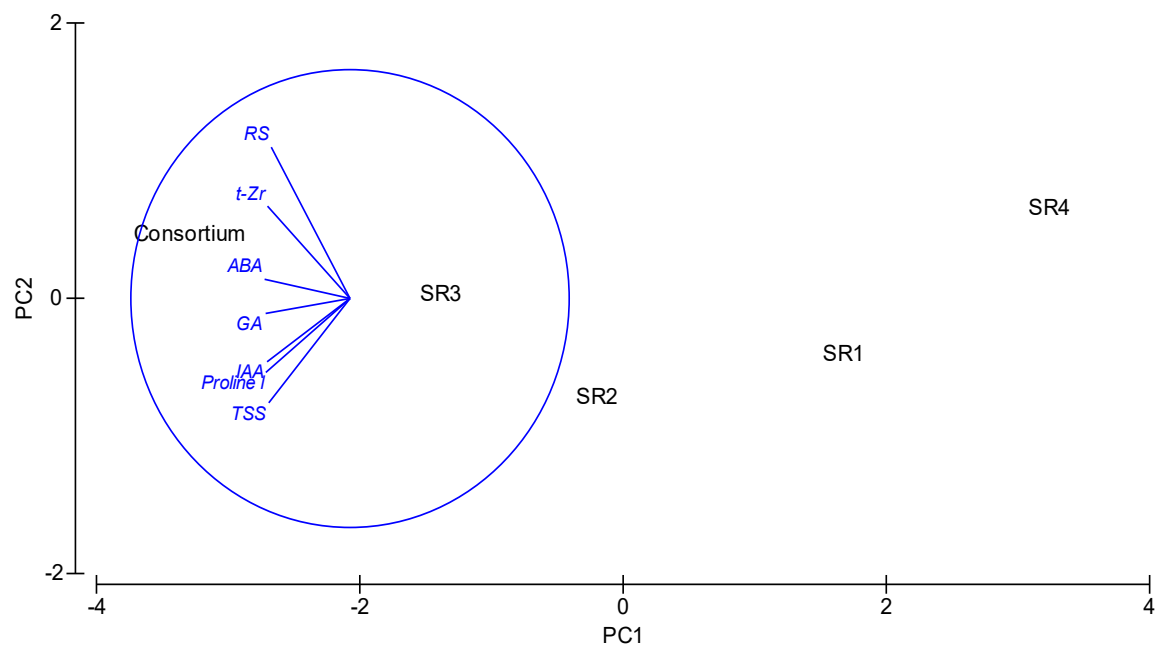

Figure 5. Principle component analysis (PCA) of phytohormones, proline, total soluble sugars, and reducing sugars of halotolerant bacterial isolates and their consortium grown under salt stress in culture conditions. Whereas, IAA = Indole acetic acid, GA = gibberellic acid, CK = Trans zeatin riboside, RS = Reducing sugars, TSS = Total soluble sugars.

\section{Discussion}

Soil bacteria associated with rhizosphere have been known as growth promotors as well as biotic and abiotic stress alleviators [8]. Bacteria associated with the roots of halophytes and saline soil, capable of tolerating higher levels of salts, are termed as halotolerant [39]. In the current study, bacterial isolates $\mathrm{SR}_{1}, \mathrm{SR}_{2}, \mathrm{SR}_{3}$, and $\mathrm{SR}_{4}$ showed the best salt tolerance abilities among all 50 bacterial isolates from the roots-soil interface of plants growing in the saline area. Phenotypic and molecular genotyping (16S RNA sequencing) of four potent isolates proved that $\mathrm{SR}_{2}$ and $\mathrm{SR}_{3}$ strains belong to 
the Azospirillum genus (Azospirillum brasilense and Azospirillum lipoferum) and the other two $\left(\mathrm{SR}_{\mathrm{I}}\right.$ and $\mathrm{SR}_{4}$ ) belong to the genus Bacillus (Bacillus sturtezi) and Pseudomonas (Paeudomonas stutzeri) (Table 2). These beneficial PGPR belonged to different genera, which indicate that plant growth promotion has been distributed across different taxons Halotolerant strains from the genera of Pseudomonas, Bacillus, Azospirillum, Klebsiella, and Ochromobacter have shown remarkable performance in the amelioration of salt stress in a wide range of crops [40].

Halotolerant PGPR has been reported to promote plant growth as well as mitigate salinity stress [41]. In the current study, we attempted to identify the key mechanisms used by halotolerant strains to alleviate the salinity stress in wheat plants by regulating plant defense mechanisms. The ability of halotolerant PGPR to produce phytohormones is associated with improved growth of plants under saline conditions [42]. The halotolerant PGPR produced IAA, GA, CK, and ABA. The results showed that Azospirillum strains produced higher amounts of GA, IAA, and CK than those of Bacillus and Pseudomonas strains in liquid media (Figure 1). The production of hormones by halotolerant PGPR is thoroughly supported by previous literature and many halotolerant strains of Azotobacter, Bacillus, Arthrobacter, Azospirillum, and Pseudomonas have been shown to produce IAA, GA, CK, and ABA [43]. These phytohormones regulate the stress defense responses in plants. They influence all aspects of plant growth, like cell wall elongation (IAA), cell division (CK), germination (gibberellin), and stress tolerance (ABA) [44-46]. Various reports suggest that these phytohormones produced under salinity stress help plants to survive and impart tolerance in them under abiotic stresses [46].

Here, the results proved that rhizobacteria secrete more compatible solutes (soluble sugars and proline) in culture media supplemented with a higher $\mathrm{NaCl}(10 \%)$ content. Various studies documented that bacterial cells can accumulate a considerable amount of compatible solutes inside their cells, acting as osmolytes and helping them to survive under severe osmotic stress [47].

Salinity is one of the common factors that can limit agricultural productivity due to its effects on seed germination, plant growth, and crop yield. Wheat is an important staple crop, but as it is a moderately salt-tolerant crop, high salt stress strictly limits its growth and development. Salt stress ultimately reduces the crop yield and nutritive value of wheat. The regulation of physiological, enzymatic, and biochemical changes in plants after inoculation with PGPR helps to alleviate salt or drought stress [40,48].

We demonstrated that salinity reduced the growth and development and relative water content of wheat plants. It also caused curling and wilting of leaves, early leaf senescence, and ultimately a reduction in the growth of plants. This is consistent with what was found in a previous study that salinity restricts cell differentiation and the cell cycle due to osmotic and ionic stress, deficiency of nutrients, oxidative damage, and limited water uptake, which affects plant germination, growth development, and physiological processes, ultimately leading to growth inhibition [49].

In this study, a consortium of four strains produced a prominent result for the dry biomass and leaf area than the control and individual inoculants. These results are in line with Walker et al. [50], who reported that inoculation with a consortium of Azospirillum-Pseudomonas-Glomus improved the root architecture in maize under salinity. A better adaptability of PGPR to stress conditions is correlated with efficient root colonization, phosphate solubilization, and nitrogen fixation abilities [51]. From the results, it is clear that salinized plants inoculated with halotolerant strains and their consortium exhibited a higher relative water content of leaves. Rakshapal et al. [52] also observed that PGPR-treated plants not only cope with stress but also that these microbes help to maintain higher water levels in comparison to control plants.

Salinity decreases the photosynthetic efficiency of plants and results in the production of reactive oxygen species (ROS), which cause damage to DNA, proteins, and membranes [53]. We described the results of photosynthetic pigments of wheat plants, which showed that treatment with a consortium showed a pronounced effect of reducing the damage caused by salinity on the photosynthetic apparatus. A similar pattern of results was reported by El-Esawi et al. [54], who observed an increase in the photosynthetic efficiency of plants by PGPR inoculation under salinity. 
Salt stress can develop more discharge of electrolytes through the misplacement of Ca associated with membranes. As a result, the permeability of the membrane is destroyed and accumulates a higher efflux of electrolytes inside plant cells/tissue [55]. In the current study, the successive increase in the electrolyte leakage of wheat plants was observed at $150 \mathrm{mM}$ salt stress than the control. These results are inconsistent with the Bojórquez-Quintal et al. [56], who found salt stress enhances electrolyte leakage and the generation of reactive oxygen species (ROS), having a detrimental effect on plant growth. Our results showed that inoculation with halotolerant PGPR tends to decrease the injurious effect of saline stress and decrease the potential electrolytic leakage of ions in stress-treated plants. This is consistent with what was found in previous studies $[57,58]$.

In the present study, the concentration of compatible solutes was also increased in inoculated wheat plants under salt stress (Table 7). The accumulation of compatible solutes, particularly proline, free amino acid, and soluble sugar, is correlated with the adaptability of the plant to stress conditions. We reported that halotolerant PGPR produces compatible osmolytes, which help the plants to maintain their ionic balance. PGPR also induce osmolyte accumulation [59] and phytohormone signaling [40], which facilitates plants in overcoming the initial osmotic shock after salinization. In a previous study, it was found that rice inoculation with salt-tolerant Bacillus amyloliquefaciens under salinity increased the plant's salt tolerance and affected the expression of genes involved in osmotic and ionic stress response mechanisms [60].

Proline is the most important osmolyte, which is produced in plants by the hydrolysis of proteins under osmotic stress [61]. From the results, it is clear that a consortium of halotolerant PGPR plants improved proline levels under salt stress. These results are in line with Wang et al. [62]. The production of osmolytes helps the plant to maintain a high turgor potential, prevent oxidative damage by scavenging reactive oxygen species, and protect the membrane structure [63].

We also reported a pronounced increase in the production of soluble sugars with a consortium of halotolerant strains in wheat under salinity stress. PGPR can stimulate carbohydrate metabolism and transport, which results in changes in the source-sink relations, photosynthesis, and growth rate. In previous reports, seeds inoculated with B. aquimaris strains showed an increased production of total soluble sugars in wheat under salinity conditions, which resulted in higher biomass and plant growth [64].

An increase in the antioxidant enzyme activity of wheat plants grown under salinity stress was observed by a consortium of halotolerant PGPR strains. This indicates that these bacteria can help the plant to combat the deleterious effects of ROS generated during salinity stress. These results tie well with the previous studies, where an increase in antioxidant enzyme activity under salinity stress was proven to be associated with salt tolerance [65]. Moreover, Wang et al. [66] reported that the application of PGPR strains alleviates the oxidative damage induced by abiotic stresses, including salinity, by augmenting the activity of antioxidant enzymes.

\section{Conclusions}

In summary, crop inoculations with halotolerant PGPR consortium can serve as a potential tool for alleviating salinity stress. Halotolerant PGPR strains have developed several mechanisms to cope with salinity, particularly the potential to produce phytohormones and compatible solutes. Halotolerant PGPR strains can induce salinity tolerance in plants by activating key defense mechanisms like the production of osmoregulators as well as activating ROS scavenging enzymes. Natural microflora adapted to saline conditions can be used for the development of microbial consortia for crop inoculation, ultimately leading to the formulation of biofertilizer for salt-stressed areas. However, further investigation is needed to observe their performance in field conditions.

Supplementary Materials: The following are available online at http://www.mdpi.com/2073-4395/10/7/989/s1, Table S1: Morphology of isolates from rhizosphere of plants from saline soil, Table S2: Preliminary screening data of isolated strains (+ indicates groeth, - indicates no growth), Table S3: Growth characters of isolated strains, Table S4: Effect of Isolates on germination attributes of wheat, Table S2: Carbon/Nitrogen source utilization pattern 
determined by QTS -24 kits, Figure S1: Phylogenetic analysis of strain SR1, Figure S2: Phylogenetic analysis of strain SR2, Figure S3: Phylogenetic analysis of strain SR3, Figure S4: Phylogenetic analysis of strain SR4.

Author Contributions: Conceptualization, N.I. Writing-Original Draft, N.I. and R.M. Formal Analysis, H.Y. and W.K. Investigation, R.M. Proofreading, H.E.E. and D.J.D. Editing, H.Y., W.K. and S.I. Formatting, D.J.D. Writing-Review, H.Y., S.I. and W.K. Supervision, N.I. Facilitation, H.E.E. Review, H.E.E. and D.J.D. All authors have read and agreed to the published version of the manuscript.

Funding: This research was funded in part by Allcosmos Industries Sdn. Bhd. through research project No. R.J130000.7344.4B200. The APC was supported by UTM-TNCPI research fund.

Conflicts of Interest: Authors have no conflict of interest.

Ethical Statement: Not applicable.

\section{References}

1. GAP Report. Global Agricultural Productivity Report (GAP Report) Global Harvest Initiative, Washington. 2018. Available online: https://globalagriculturalproductivity.org/wp-content/uploads/2019/01/GHI_2018GAP-Report_FINAL-10.03.pdf (accessed on 5 May 2020).

2. Abbas, R.; Rasul, S.; Aslam, K.; Baber, M.; Shahid, M.; Mobeen, F.; Naqqash, T. Halo-tolerant PGPR: A hope for cultivation of saline soils. J. King Saud Univ. Sci. 2019, 31, 1195-1201. [CrossRef]

3. Mishra, J.; Fatima, T.; Arora, N.K. Role of secondary metabolites from plant growth-promoting rhizobacteria in combating salinity stress. In Plant Microbiome: Stress Response; Ahmad, P., Egamberdieva, D., Eds.; Springer: Singapore, 2018; pp. 127-163.

4. Yasin, N.A.; Khan, W.; Ahmad, S.R.; Ali, A.; Ahmad, A.; Akram, W. Imperative roles of halo-tolerant plant growth-promoting rhizobacteria and kinetin in improving salt tolerance and growth of black gram (Phaseolusmungo). Environ. Sci. Pollut. Res. 2017, 25, 4491-4505. [CrossRef]

5. Abdel-Latef, A.A.H.; Chaoxing, H. Does Inoculation with Glomus mosseae Improve Salt Tolerance in Pepper Plants? J. Plant Growth Regul. 2014, 33, 644-653. [CrossRef]

6. Liu, K.; McInroy, J.A.; Hu, C.-H.; Kloepper, J.W. Mixtures of Plant-Growth-Promoting Rhizobacteria Enhance Biological Control of Multiple Plant Diseases and Plant-Growth Promotion in the Presence of Pathogens. Plant Dis. 2018, 102, 67-72. [CrossRef]

7. Khan, A.; Zhao, X.Q.; Javed, M.T.; Khan, K.S.; Bano, A.; Shen, R.F. Bacillus pumilus enhances tolerance in rice (Oryza sativa L.) to combined stresses of $\mathrm{NaCl}$ and high boron due to limited uptake of $\mathrm{Na}$. Environ. Exp. Bot. 2016, 124, 120-129. [CrossRef]

8. Yasmin, H.; Nosheen, A.; Naz, R.; Keyani, R.; Anjum, S. Regulatory role of rhizobacteria to induce drought and salt stress tolerance in plants. In Field Crops: Sustainable Management by PGPR. Sustainable Development and Biodiversity; Maheshwari, D., Dheeman, S., Eds.; Springer: Cham, Switzerland, 2019; Volume 23, p. 23.

9. Niu, X.; Song, L.; Xiao, Y.; Ge, W. Drought-tolerant plant growth-promoting rhizobacteria associated with foxtail millet in a semi-arid agroecosystem and their potential in alleviating drought stress. Front. Microbiol. 2018, 8, 2580. [CrossRef] [PubMed]

10. Chu, T.N.; Tran, B.T.H.; Van-Bui, L.; Hoang, M.T.T. Plant growth-promoting rhizobacterium Pseudomonas PS01 induces salt tolerance in Arabidopsis thaliana. BMC Res. Notes 2019, 12, 11. [CrossRef] [PubMed]

11. Radojevic, M.; Bashkin, V.N. Practical Environmental Analysis; The Royal Society of Chemistry: Cambridge, UK, 1999; p. 466.

12. Soltanpour, P.N.; Schwab, A.P. A new soil test for simultaneous extraction of macro- and micro-nutrients in alkaline soils. Commun. Soil Sci. Plant Anal. 1977, 8, 195-207. [CrossRef]

13. Kingston, H.M. Microwave Assisted Acid Digestion of Sediments, Sludges, Soils and Oils; Duquesne University: Pittsburgh, PA, USA, 1994; p. 4.

14. Somasegaran, P.; Hoben, H.J. Counting rhizobia by a plant infection method. In Handbook for Rhizobia; Springer: New York, NY, USA, 1994; pp. 58-64.

15. James, G.C. Native Sherman Rockland Community College, State University of New York; The Benjamin/Coming Publishing Company Inc.: San Francisco, CA, USA, 1987; pp. 75-80.

16. Robinson, R.J.; Fraaije, B.A.; Clark, I.M.; Jackson, R.W.; Hirsch, P.R.; Mauchline, T.H. Endophytic bacterial community composition in wheat (Triticum aestivum) is determined by plant tissue type, developmental stage and soil nutrient availability. Plant Soil 2016, 405, 381-396. [CrossRef] 
17. Pikovskaya, R. Mobilization of phosphorus in soil in connection with vital activity of some microbial species. Mikrobiologiya 1948, 17, 362-370.

18. Murphy, J.A.M.E.S.; Riley, J.P. A modified single solution method for the determination of phosphate in natural waters. Anal. Chim. Acta 1962, 27, 31-36. [CrossRef]

19. Schwyn, B.; Neilands, J.B. Universal chemical assay for the detection and determination of siderophores. Anal. Biochem. 1987, 160, 47-56. [CrossRef]

20. Lorck, H. Production of hydrocyanic acid by bacteria. Physiol. Plant. 1948, 1, 142-146. [CrossRef]

21. Noreen, Z.; Ashraf, M.; Hassan, M.U. Inter-accessional variation for salt tolerance in pea (Pisum sativum L.) at germination and screening stage. Pak. J. Bot. 2007, 39, 2075-2085.

22. Upadhyay, S.K.; Singh, J.S.; Singh, D.P. Exopolysaccharide-producing plant growth-promoting rhizobacteria under salinity condition. Pedosphere 2011, 21, 214-222. [CrossRef]

23. Tien, T.M.; Gaskins, M.H.; Hubbell, D.H. Plant growth substances produced by Azospirillum brasilense and their effect on the growth of pearl millet (Pennisetum americanum L.). Appl. Environ. Microbiol. 1979, 37, 1016-1024. [CrossRef] [PubMed]

24. Chen, W.P.; Kuo, T.T. A simple and rapid method for the preparation of gram-negative bacterial genomic DNA. Nucleic Acids Res. 1993, 21, 2260. [CrossRef]

25. Weisburg, W.G.; Barns, S.M.; Pelletier, D.A.; Lane, D.J. $16 \mathrm{~S}$ ribosomal DNA amplification for phylogenetic study. J. Bacteriol. 1991, 173, 697-703. [CrossRef]

26. Eck, R.V.; Dayhoff, M.O. Atlas of Protein Sequence and Structure; National Biomedical Research Foundation: Silverspring, MD, USA, 1966; p. 12.

27. Unyayer, S.; Keles, Y.; Cekic, F.O. The antioxidative response of two tomato species with different tolerances as a result of drought and cadmium stress combination. Plant Soil Environ. 2005, 51, 57-64. [CrossRef]

28. Sriram, S.; Raguchander, T.; Babu, S.; Nandakumar, R.; Shanmugam, V.; Vidhyasekaran, P. Inactivation of phytotoxin produced by the rice sheath blight pathogen Rhizoctonia solani. Can. J. Microbiol. 2000, 46, 520-524. [CrossRef]

29. Arnon, D.I. Copper enzymes in isolated chloroplasts. Polyphenol oxidase in Beta vulgaris. Plant Physiol. 1949, 24, 1-15. [CrossRef] [PubMed]

30. Bates, L.S.; Waldren, R.P.; Teare, I.D. Rapid determination of free proline for water stress studies. Plant Soil 1973, 39, 205-207. [CrossRef]

31. Dubois, M.; Gilles, K.A.; Hamilton, J.K.; Rebers, P.A.; Smith, F. A colorimetric method for the determination of sugars. Nature 1951, 168, 167. [CrossRef] [PubMed]

32. Hamilton, P.B.; VanSlyke, D.D. Amino acid determination with ninhydrin. J. Biol. Chem. 1943, 150, $231-233$.

33. Bradford, M. A rapid and sensitive method for the quantitation of microgram, quantitation of proteins utilizing the principle of protein dye-binding. Anal. Biochem. 1976, 72, 248-254. [CrossRef]

34. Aebi, H. Catalase in Vitro. Methods Enzymol. 1984, 105, 121-126. [CrossRef]

35. Rao, M.V.; Paliyath, G.; Ormrod, D.P. Ultraviolet-B- and ozone induced biochemical changes in antioxidant enzymes of Arabidopsis thaliana. Plant Physiol. 1996, 110, 125-136. [CrossRef]

36. Giannopolitis, C.N.; Ries, S.K. Superoxide dismutase in higher plants. Plant Physiol. 1977, 59, 309-314. [CrossRef]

37. Steel, R.G.D.; Torrie, G.H. Principles and Procedures of Statistics Singapore, 2nd ed.; McGraw Hill Book Co Inc.: New York, NY, USA, 1980.

38. Tamura, K.; Dudley, J.; Nei, M.; Kumar, S. MEGA4: Molecular evolutionary genetics analysis (MEGA) software version 4.0. Mol. Boil. Evol. 2007, 24, 1596-1599. [CrossRef]

39. Ramadoss, D.; Lakkineni, V.K.; Bose, P.; Ali, S.; Annapurna, K. Mitigation of salt stress in wheat seedlings by halotolerant bacteria isolated from saline habitats. SpringerPlus 2013, 2, 6. [CrossRef]

40. Egamberdieva, D.; Wirth, S.; Bellingrath-Kimura, S.D.; Mishra, J.; Arora, N.K. Salt-Tolerant Plant Growth Promoting Rhizobacteria for Enhancing Crop Productivity of Saline Soils. Front. Microbiol. 2019, 10, 2791. [CrossRef] [PubMed]

41. Sarkar, A.; Ghosh, P.K.; Pramanik, K.; Mitra, S.; Soren, T.; Pandey, S. A halo-tolerant Enterobacter sp. displaying ACC deaminase activity promotes rice seedling growth under salt stress. Microbiol. Res. 2018, 169, $20-32$. [CrossRef] [PubMed]

42. Patel, D.; Saraf, M. Influence of soil ameliorants and microflora on induction of antioxidant enzymes and growth promotion of (Jatropha curcas L.) under saline condition. Eur. J. Soil Biol. 2013, 55, 47-54. [CrossRef] 
43. Abd-Allah, E.F.; Alqarawi, A.A.; Hashem, A.; Radhakrishnan, R.; Al-Huqail, A.A.; Al-Otibi, F.A. Endophytic bacterium Bacillus subtilis (BERA 71) improves salt tolerance in chickpea plants by regulating the plant defense mechanisms. J. Plant Interact. 2017, 3, 37-44. [CrossRef]

44. TrParray, A.P.; Jan, S.; Kamili, A.N.; Qadri, R.A.; Egamberdieva, D.; Ahmad, P. Current perspectives on plant growth promoting rhizobacteria. J. Plant Growth Regul. 2016, 35, 877-902. [CrossRef]

45. Salomon, M.; Bottini, R.; de Souza Filho, G.A.; Cohen, A.C.; Moreno, D.; Gil, M. Bacteria isolated from roots and rhizosphere of Vitis vinifera retard water losses, induce abscisic acid accumulation and synthesis of defense-related terpenes in in vitro cultured grapevine. Physiol. Plant. 2014, 151, 359-374. [CrossRef] [PubMed]

46. Bottini, R.; Cassán, F.; Piccoli, P. Gibberellin production by bacteria and its involvement in plant growth promotion and yield increase. Appl. Microbiol. Biotechnol. 2004, 65, 497-503. [CrossRef]

47. Parida, A.K.; Das, A.B. Salt tolerance and salinity effect on plants: A review. Ecotoxicol. Environ. Saf. 2005, 60, 324-349. [CrossRef]

48. Kumar, A.; Verma, J.P. Does plant-microbe interaction confer stress tolerance in plants: A review? Microbiol. Res. 2018, 207, 41-52. [CrossRef]

49. Isayenkov, S.V.; Maathuis, F.J.M. Plant Salinity Stress: Many Unanswered Questions Remain. Front. Plant Sci. 2019, 10, 80. [CrossRef]

50. Walker, V.; Couillerot, O.; Felten, A.V.; Bellvert, F.; Jansa, J.; Maurhofer, M.; Bally, R.; Moënne-Loccoz, Y.; Comte, G. Variation of secondary metabolite levels in maize seedling roots induced by inoculation with Azospirillum, Pseudomonas and Glomus consortium under field conditions. Plant Soil 2012, 356, 151-163. [CrossRef]

51. Nadeem, S.M.; Zahir, Z.A.; Naveed, M.; Arshad, M. Preliminary investigations on inducing salt tolerance in maize through inoculation with rhizobacteria containing ACC deaminase activity. Can. J. Microbiol. 2007, 53, 1141-1149. [CrossRef] [PubMed]

52. Rakshapal, S.; Sumit, K.S.; Rajendra, P.P.; Alok, K. Technology for improving essential oil yield of Ocimum basilicum L. (sweet basil) by application of bioinoculant colonized seeds under organic field conditions. Ind. Crop. Prod. 2013, 45, 335-342. [CrossRef]

53. Islam, F.; Yasmeen, T.; Arif, M.S.; Ali, S.; Ali, B.; Hameed, S. Plant growth promoting bacteria confer salt tolerance in Vigna radiata by up-regulating antioxidant defense and biological soil fertility. Plant Growth Regul. 2016, 80, 23-36. [CrossRef]

54. El-Esawi, M.A.; Alaraidh, I.A.; Alsahli, A.A.; Alamri, S.A.; Ali, H.M.; Alayafi, A.A. Bacillus firmus (SW5) augments salt tolerance in soybean (Glycine max L.) by modulating root system architecture, antioxidant defense systems and stress-responsive genes expression. Plant Physiol. Biochem. 2018, 132, 375-384. [CrossRef]

55. Garg, N.; Manchanda, G. Role of arbuscular mycorrhizae in the alleviation of ionic, osmotic and oxidative stresses induced by salinity in Cajanus cajan (L.) Millsp. (pigeonpea). J. Agron. Crop Sci. 2009, 195, 110-123. [CrossRef]

56. Bojórquez-Quintal, E.; Velarde-Buendía, A.; Ku-González, Á.; Carillo-Pech, M.; Ortega-Camacho, D.; Echevarría-Machado, I.; Pottosin, I.; Martínez-Estévez, M. Mechanisms of salt tolerance in habanero pepper plants (Capsicum chinense Jacq.): Proline accumulation, ions dynamics and sodium root-shoot partition and compartmentation. Front. Plant Sci. 2014, 5, 605. [CrossRef]

57. Kaya, C.; Tuna, A.L.; Okant, A.M. Effect of foliar applied kinetin and indole acetic acid on maize plants grown under saline conditions. Turk. J. Agric. For. 2010, 34, 529-538.

58. Habib, S.H.; Kausar, H.; Saud, H.M. Plant Growth-Promoting Rhizobacteria Enhance Salinity Stress Tolerance in Okra through ROS-Scavenging Enzymes. BioMed Res. Int. 2016, 2016, 6284547. [CrossRef]

59. Bremer, E.; Kramer, R. Responses of microorganisms to osmotic stress. Annu. Rev. Microbiol. 2019, 73, 313-334. [CrossRef]

60. Nautiyal, C.S.; Srivastava, S.; Chauhan, P.S.; Seem, K.; Mishra, A.; Sopory, S.K. Plant growth-promoting bacteria Bacillus amyloliquefaciens NBRISN13 modulates gene expression profile of leaf and rhizosphere community in rice during salt stress. Plant Physiol. Biochem. 2013, 66, 1-9. [CrossRef] [PubMed]

61. Krasensky, J.; Jonak, C. Drought, salt, and temperature stress-induced metabolic rearrangements and regulatory networks. J. Exp. Bot. 2012, 63, 1593-1608. [CrossRef] [PubMed] 
62. Wang, Q.; Dodd, I.C.; Belimov, A.A.; Jiang, F. Rhizosphere bacteria containing 1-aminocyclopropane1-carboxylate deaminase increase growth and photosynthesis of pea plants under salt stress by limiting $\mathrm{Na}+$ accumulation. Funct. Plant Biol. 2016, 43, 161-172. [CrossRef] [PubMed]

63. Prado, F.E.; Boero, C.; Gallardo, M.; González, J.A. Effect of $\mathrm{NaCl}$ on germination, growth, and soluble sugar content in Chenopodium quinoa wild seeds. Bot. Bull. Acad. Sin. 2000, 41, 27-343.

64. Upadhyay, S.K.; Singh, D.P. Effect of salt-tolerant plant growth-promoting rhizobacteria on wheat plants and soil health in a saline environment. Plant Biol. (Stuttg.) 2015, 17, 288-293. [CrossRef] [PubMed]

65. Moghaddam, M.; Farhadi, N.; Panjtandoust, M.; Ghanati, F. Seed germination, antioxidant enzymes activity and proline content in medicinal plant Tagetes minuta under salinity stress. Plant Biosyst. 2019. [CrossRef]

66. Wang, C.J.; Yang, W.; Wang, C.; Gu, C.; Niu, D.D.; Liu, H.X.; Wang, Y.P.; Guo, J. Induction of drought tolerance in cucumber plants by a consortium of three plant growth-promoting rhizobacterium strains. PLoS ONE 2012, 7, e52565. [CrossRef]

(C) 2020 by the authors. Licensee MDPI, Basel, Switzerland. This article is an open access article distributed under the terms and conditions of the Creative Commons Attribution (CC BY) license (http://creativecommons.org/licenses/by/4.0/). 